\title{
COMMUNICATION IN THE THIRD DIMENSION. LEGAL ASPECTS OF USING DRONES IN THE CITY AREA
}

\author{
Tomasz SZEWC \\ Silesian University of Technology; Tomasz.Szewc@polsl.pl, ORCID: 0000-0001-6326-4626
}

\begin{abstract}
Purpose: A new regulation concerning drone flights is entering into force from the January 1, 2021 and the public administration uses drones to carry out public tasks more and more often. This poses new challenges for the public administration to adapt to new rules. This article presents new regulation concerning drone operations from the public administration management perspective.
\end{abstract}

Design/methodology/approach: A study of the literature and legal acts was made.

Findings: Public administration bodies can freely use drones to carry out public tasks and do not need a specific legal basic to this, but it involves considering the form of drone use by themselves or in cooperation with specialized company. The main problem seems sharing the airspace with other users, since the law do not confer priority for public use of drones.

Practical implications: The research shows some limits and obstacles while public administration bodies uses drones to carry out public tasks as well as ways to overcome them.

Social implications: What will be the impact on society of this research? How will it influence public attitudes? How will it influence (corporate) social responsibility or environmental issues?

Originality/value: This is one of the first analysis of new drone law from the public administration bodies point of view in the Polish scientific literature. It may came into handy for local self-government management, especially for cities.

Keywords: drone, unmanned aircraft, public tasks, public administration.

Category of the paper: Research paper.

\section{A drone in the city area}

A drone is a colloquial name for the unmanned aerial vehicle (UAV), i.e. a vehicle lifting in the air without a human being on the board. Lately, these devices are becoming more and more popular. Also in Poland efforts are being made to utilize this technology most efficiently. According to the Polish government's plans, the Silesian Voivodship is expected to become the Polish "Silicon Valley" in terms of drones usage, and drones are planned to be used by the 
public administration. This possibility is being tested under so-called "Żwirko and Wigura Programme" (Darowska, 2019).

Ease and low cost of accessing hard-to-reach places as well as the possibility of image transfer are the main reasons for the rising drones' popularity. These features allow the drones to replace humans in various activities. Autonomous operation is an extra ability of the drones, thanks to which the UAVs can be used in monitoring or inspection of any object, air quality testing, geodetic or thermovision measurements, crop inventory, transportation of diversified loads, as well as in supporting firefighting or rescue operations (Dziekański, 2019). One cannot forget also recreational or sport use of the UAVs.

The city creates a specific environment for the drones. On the one hand, the city has its particular needs. On the other hand, there are certain impediments, making the drones' use more difficult and complicated.

When it comes to the city needs, by transferring communication to the third dimension (air) the drones help in solving the problems of the traffic congestion and communication limits (i.e. limited capacity of roads, railroads, bottlenecks, etc.). Moreover, the drones can perform their tasks between high buildings and in vast industrial areas. Thanks to the real-time data transfer to computing centers, UAVs perfectly fit the Smart City concept which assumes the use of information technology and digital data transfers to rationalize management of city resources and hence, obtain sustainable development and many other positive effects, including social, ecological, and economic. All these above utilities of drones can be integrated. This holistic approach will lead to the faster city development (Appio et al., 2019; Höjer, and Wangel, 2015; Jonek-Kowalska, and Wolniak, 2019) as well as to the decrease in city management costs (Anttiroiko et al., 2014).

When it comes to the impediments hindering the use of drones in the city, we need to mention several risk factors, including high barriers, chances to lose visual and/or control over a UAV, possibility of a collision with people or objects, and the need to reduce noise emission. Also, we must note that the number of drones is rising, and additionally, recreational flights are becoming more and more popular, hence we may expect the drone traffic in the cities to intensify.

Users of drones can be divided into 3 groups:

a) business entities using drones to run businesses,

b) official authorities performing public tasks,

c) private persons using drones to satisfy their needs.

Since the volume of this article is strictly limited, we will refer mostly to using drones by the city authorities in the light of new EU regulations. This is one of the latest practical and theoretical issues in the field of city area management (especially Smart City), at the same less recognized in the literature. 


\section{Drones in the light of the law}

Numerous legal provisions are specifying the rules of drone flights. Most of all, drone as an airship is a subject to the aviation law. Until the end of 2020, specific national regulations governing drone flights are in force in each country of the EU. This is going to change on the 1 st of January 2021 when the national laws will be repealed and replaced by the common EU regulations. Furthermore, if a drone is equipped with a camera allowing to register a person's image while flying, it will be subject to the rules concerning personal data protection.

There are also certain laws directly allowing public administration institutions to perform public tasks with the help of drones. We can mention e.g. art. 49 paragraph 3a of the Entrepreneurs Law Act and art. 9 paragraph 2 point 2 of Environmental Protection Inspection Act. But the most important legal act governing this field is the Regulation 2019/947, describing the rules and procedures of the unmanned aircraft operation. This legal act specifies the requirements for the drone operators determined solely on the risk involved in the operation (they are presented e.g. in points 3,6, and 9 of the preamble). Thus, the nature of the drone operation (commercial or recreational) and the character of the operator carrying out the operation (representing the public or private sector) become irrelevant. Consequently, the above-mentioned act distinguishes three categories of drone operations: open, specific, and certified.

An "open" category includes operations with the lowest risk level. Such an operation should meet all the following requirements:

1. a drone complies with requirements laid down in separate provisions, particularly it belongs to one of the classes indicated in this regulation,

2. its take-off weight does not exceed $25 \mathrm{~kg}$,

3. a drone is kept at a safe distance from people,

4. a drone does not fly over assemblies of people,

5. a drone does not drop any materials,

6. a drone does not carry any dangerous goods (i.e. articles or substances that are capable of posing a hazard to health, safety, property, or the environment in the case of an incident or accident, e.g. explosives, flammables, toxic or infectious substances),

7. a remote pilot maintains full control over a drone all the time (meaning that the drone is in the pilot's visual line of sight at all times except when flying in the follow-me mode or when using an aircraft observer remaining in constant contact with the pilot),

8. during the flight, the drone is maintained within 120 meters from the closest point of the surface of the earth, except when overflying an obstacle. This relates to another requirement, particularly important in the city environment and described in part A of the Annex to the regulation, recommending that while flying within a horizontal distance of 50 meters or less from an artificial obstacle taller than 105 meters, the maximum height of UAV operation may be increased up to 15 meters above the height of the obstacle, if the entity responsible for the obstacle demands it. 
Performing an operation classified into the open category does not require any permission, however, a remote pilot $^{1}$ should possess proper qualifications, depending on the subcategory of the performed flight. There are three subcategories: A1, A2, and A3. Subcategory A1 is for operations performed by drones the maximum take-off weight of which does not exceed 900 grams when a remote pilot does not overfly assemblies of people. Furthermore the remote pilot shall reduce as much as possible the time during which the unmanned aircraft overflies uninvolved persons. In subcategory A2, including drones with a take-off weight up to 4 kilograms, operations within the minimum distance of 30 meters from uninvolved people are allowed. This distance can be reduced to 5 meters only if a drone has an active low-speed mode and a remote pilot is able to consider weather conditions, the performance of the aircraft, and segregation of the overflown area in an adequate way. Subcategory A3 in turn includes drones with a take-off weight up to 25 kilograms, performing operations outside residential, industrial, commercial and recreational areas where the remote pilot reasonably expects that no uninvolved person will be endangered by the aircraft during the entire time of the operation. For this UAV type, a horizontal distance of at least 150 meters should be maintained between them and any other objects.

To be allowed to perform an operation of A1 and A3 subcategory a remote pilot should complete an online training course and pass an online exam except if a drone is lighter than 250 grams (hence, in fact flying a drone below this weight does not require any formal qualifications from a remote pilot). Unlike the previous ones, in the case of performing A2 operation, extra requirements must be met by the pilot. In addition to completing the course, self-practical training must be performed and confirmed by the future pilot's declaration. Moreover, the pilot should pass an additional theoretical exam provided by the competent authority and allowing to assess the remote pilot's knowledge of the technical and operational mitigations for ground risks.

If an operation performed by an unmanned aircraft operator does not meet even a single requirement set out for the open category or is not considered to be the last one (explained further in the text), it becomes an operation of the second, i.e. "specific" category. Such an operation can be legally performed in three ways. Firstly, on the grounds of an operational authorization from the competent authority (which in Poland is the Civil Aviation Authority, CAA). The subject of an operational authorization can be an operator or a model aircraft club and association. Secondly, an operator can hold a LUC certificate (which stands for the Light UAV Operator Certificate). In such a case an operator is authorized to certify an operation by themselves (Ostrihansky, and Szmigiero, 2020). Thirdly, an operator can submit a declaration to the CAA where they declare that the operation will comply with a standard scenario, setting out specific condition of flight (being an appendix to the Annex B to the resolution 2019/947). 
The operation belongs to the third category, the "certified" one, in two cases. The first situation is when a drone is certified under separate regulations and the operation is performed over assemblies of people, or involves the transportation of people or dangerous goods, which may result in high risk for third parties in case of an accident. The second situation happens when an operation is assessed by the CAA as too risky to be performed abiding by rules set out for a specific category. Certified operations involve certification of the operator, the aircraft, and the licensing of a remote pilot. In practice, it means that the requirements are increased up to the level characteristic for the manned flights (Ostrihansky, adnd Szmigiero, 2020).

\section{Carrying out public tasks of the city with the benefit of drones}

Having regarded the general principles of drone flights, we should refer to utilizing drones in performing city tasks. Concerning this topic, we can base on the concept presented by M. Dziekański who describes various examples of drones usage by the territorial selfgovernment entities (Dziekański, 2019). Even though they are different tasks, the ways the drones are used in the city are very similar. In most cases, they allow approaching places that are difficult or impossible to access in another way, and/or capturing and sending pictures or videos. So, which type of drones and which type of operations can be used for these purposes?

Drones with a maximum take-off weight lower than 250 grams (remote piloting of which does not require any confirmed qualifications), seem to be inappropriate to perform these tasks because of a too short range. They can spend in the air only from a couple to several minutes which may be insufficient, e.g. to inspect a big bridge. Moreover, the open category can not be taken into account when planning the task of carrying goods, especially dangerous ones. Such a danger may pose e.g. transportation of blood samples from a hospital to a laboratory that in fact represents one of the typical public tasks performed in the city. One can easily imagine the consequences of a potential crash of the UAV carrying e.g. infected blood. This category is unsuitable also because it requires performing flights within a visual line of sight and it is difficult to meet this criterion because there are tall buildings in the city and a drone can be obscured by them. Furthermore, it is worth noting that it is autonomous flights that are expected to be the most commonly used type of drone operations in the future (Przybylski, 2020; Jóźwiak, and Ławnicka, 2019) but autonomous flights can not be performed under open category.

The above notions lead to the conclusions that drones heavier than 250 grams should be used to carry out public tasks and that the city authorities will mostly perform operations representing a specific or even certified category. These categories in turn bring much higher requirements not only for the drone pilots (i.e. demand their higher qualifications) but also for their operators (set out in the Annex A to the Regulation 2019/947). The authorities of the city 
should meet them by themselves, which incurs additional expenses, or establish cooperation with an external operator. To make this decision, careful financial analyses should be performed, considering the costs of acquiring drones, staff training, elaboration of the necessary documentation, versus the costs of hiring the external operator. If the city decides to cooperate with a specialized enterprise, this collaboration may have various legal bases in the light of Polish law. It may be treated as the provision of services within the frameworks of either public procurement, public-private partnership, or even concessions for construction works and services.

Considering the legal basis of using the drones (i.e. by the city itself or provided by an external operator) it is worth noting that there is an obstacle to hire remote pilots by local self-government entities. This obstacle derives from rules specifying positions and qualification requirements set for them in the local self-government. These rules do not establish such a position as a remote pilot in the local self-government authority (the government regulation from May 15, 2018, on the remuneration of local government employees, Journal of Laws, item 936 with amendments). Hence, only people already working for the city and occupying other positions (e.g. a city warden or an employee in a city conservation authority) may become remote pilots and accept more duties after extending their qualifications.

There are only a few provisions setting up the possibility of using drones to carry out public tasks as mentioned above. This causes the problem of finding a legal basis to make flights. M. Dziekanski drew attention to this fact (Dziekański, 2019) by pointing out the article no. 7 of the Polish Constitution. In the light of this provision, public authorities act on a basis and within the limits of the law. So, when there is a specific rule, the flights carrying out public tasks can be performed. But what to do when a case is unregulated? This question can be explained and solved by a concept of legal forms of administrative activity elaborated by the administrative law doctrine. This form is a "legally set out type of specific activity of an administrative body" (Starościak, 1969, p. 231). For example, administrative authorities carrying out the imposed tasks perform different activities: lay down legal acts, make administrative decisions, keep registers, take various actions: technical (e.g. building a new road), organizational (e.g. preparing a public tender), and managerial ones (e.g. maintain cleanliness) (Ochendowski, 2005). These forms can be divided into legal acts (involving a declaration of a will prepared with an intention to produce legal effects) and physical acts (with no such intention). Only the first group of actions requires a directly expressed legal basis. Therefore a rule establishing general competence of an authority to perform some tasks is sufficient to perform physical acts (Zimmermann, 2016), e.g. local public transport or infrastructure monitoring, (Dziekański, 2019). There is no doubt that a drone flight is a physical activity because it does not cover a declaration of will, and depending on the purpose, the flight can be a technical action (e.g. emission measurement), or organizational action (e.g. transportation of goods), or managerial action (e.g. infrastructure monitoring). Consequently, there is no fear that a lack of an expressed legal basis makes drone flights performing public tasks of the city illegal. 


\section{Summary}

Unmanned aircraft represents technology able to considerably change the shape of modern society, including the way public tasks are performed. It is understandable that the public administration, constantly looking for efficient ways to carry out their tasks, begins to reach for drones. Their use as a means of performing public administration actions is generally not regulated by the law (with few exceptions), this, however, does not pose a greater obstacle because this type of administrative activity does not need a specific legal basis. However, the administrative body using a UAV should abide by rules specific to this communication means, i.e. the aviation law. Additionally, it is local authorities' employees (directed to work with drones) who will be obliged to develop adequate qualifications.

The main obstacle the cities using drones need to face is the necessity to share the airspace with many other users from both the commercial and private sectors. For that reason, it is worth conferring priority for an unmanned aircraft performing public tasks. Below there are some ways to ensure such a priority resulting from the currently binding law:

a) assigning geographical zones ${ }^{2}$ reserved only for drones carrying out public tasks in selected areas of the city;

b) the ban to fly close to or inside areas where an emergency response effort is ongoing without permission to do so from the responsible emergency response services, set out in the Annexe A to the Regulation 2019/947;

c) securing possibility to make in domestic law an exemption for the specific and certified operations performed in the field of traffic surveillance, environment protection, medical or evacuation flights from the requirements set out in Regulation 923/2012, laying down the common rules of the air and operational provisions regarding services and procedures in air navigation (Ostrihansky, and Szmigiero, 2020). However, it is worth to mention that the scope of these exemptions is still very narrow).

In concluding we may note that the EU lawmakers seem not to consider performing public tasks with the use of drones as deserving the priority in comparison with other flights. Hence, a high volume of private flights can be expected. Consequently, a detailed map of routes for drones as well as an efficient drone traffic management system should be created. They should regard obstacles, strategic and dangerous-to-fly-over facilities, or noise emission requirements (Miasta, 2018). Such works are carried out within the U-Space Demonstrator program (Darowska, 2019). 


\section{References}

1. Anttiroiko, A.V., and Valkama, P., and Bailey, S. (2014). Smart Cities in the New Service Economy: Building Platforms for Smart Services. AI \& Society, Vol. 29, pp. 323-334.

2. Appio, F.P., Lima, M., Paroutis, S. (2019). Understanding Smart Cities: Innovation ecosystems, technological advancements, and societal challenges. Technological Forecasting and Social Change, Vol. 142, pp. 1-14.

3. Commission Implementing Regulation (EU) 2019/947 describing the rules and procedures of the unmanned aircraft operation. Official Journal L152, p. 45 (2019).

4. Commission Implementing Regulation (EU), No 923/2012, laying down the common rules of the air and operational provisions regarding services and procedures in air navigation and amending Implementing Regulation (EU) No 1035/2011 and Regulations (EC) No 1265/2007, (EC) No 1794/2006, (EC) No 730/2006, (EC) No 1033/2006 and (EU) No 255/2010, Official Journal L281, p. 1 (2012).

5. Darowska, M. (2019). Kierunek rozwoju rynku dronów. IT w administracji, Vol. 11, pp. 16-20.

6. Dziekański, M. (2019). Wykorzystanie dronów przez administrację samorządową. IT $w$ administracji, Vol. 11, pp. 20-22.

7. Entrepreneurs Law Act, Journal of Laws 2019, item 1292 (2018).

8. Environmental Protection Inspection Act, Journal of Laws 2020, item 995 (1991).

9. Höjer, M., and Wangel, J. (2015). Smart Sustainable Cities: Definition and Challenges. In: L.M. Hilty, and B. Aebisch (eds.), ICT Innovations for Sustainability. Advances in Intelligent Systems and Computing (pp. 333-349). Zurych: Springer International Publishing.

10. Jonek-Kowalska, I., and Wolniak, R. (2019). Holistyczne podejście do rozwoju inteligentnych miast. In: I. Jonek-Kowalska (ed.), Wyzwania i uwarunkowania zarządzania inteligentnymi miastami (pp. 23-39). Zabrze: Wydawnictwo Politechniki Śląskiej.

11. Jóźwiak, Z., and Ławnicka, B. (2019). Trzeci wymiar miasta, czyli dronostrada pełna podniebnych usług. Gazeta Prawna, Iss. 28.06.2019.

12. Miasta będą musiały zapanować nad dronami. Gazeta Prawna, Iss. 28.11.2008.

13. Ochendowski, E. (2005). Prawo administracyjne. Torun: TNOiK.

14. Ostrihansky, M., and Szmigiero, M. (2020). Prawo dronów. Bezzałogowe statki powietrzne w prawie Unii Europejskiej oraz w prawie krajowym. Warszawa: Wolters Kluwer.

15. Polish Constitution, Journal of Laws, 1997, No. 78, item 483 (1997).

16. Przybylski, R. (2020). Otwarte niebo dla bezzałogowców. Małgorzata Darowska o wspieraniu nowych technologii. Rzeczpospolita, Iss. 20.05.2020.

17. Starościak, J. (1969). Prawo administracyjne. Warszawa: PWN.

18. Zimmermann, J. (2016). Prawo administracyjne. Warszawa: Wolters Kluwer. 


\section{Footnotes}

${ }^{1}$ We should make a distinction between a remote pilot, who is a person who pilotes a drone and an operator who is an entity who uses (operates) drones in its activity as an owner or leasee. It can be a legal or a natural person.

${ }^{2}$ Geographical zone is a portion of airspace that facilitates, restricts or excludes drones operations in order to address risks pertaining to safety, privacy, protection of personal data, security or the environment (art. 2, point 4 or regulation 2019/947). 